\footnotetext{
JURNAL CEMERLANG: Pengabdian pada Masyarakat

P-ISSN 2654-4741 / E-ISSN 2655-7894

Vol. 4, No. 1, Desember 2021, 98 - 108

DOI: https://doi.org/10.31540/jpm.v4i1.1424

PENERBIT: LP4MK STKIP PGRI LUBUKLINGGAU
}

\title{
PENINGKATAN PENGETAHUAN ANIMASI VIDEO DAN ROBOTIK DALAM PENERAPAN PROJECT BASE LEARNING DI SMA IT BAITUL JANNAH
}

\author{
Arlina Phelia, Galuh Pramita, Try Susanto, Agus Widodo, Rio Aditomo \\ Mahardika Putra \\ Universitas Teknokrat Indonesia, Jl. ZA. Pagar Alam No.9 -11, Labuhan Ratu \\ Kec. Kedaton, Kota Bandar Lampung, Indonesia \\ Email: arlina.phelia@ teknokrat.ac.id
}

\begin{abstract}
ABSTRAK
Peningkatan kualitas Pendidikan menjadikan perkembangan teknologi semakin meningkat pula dan memaksa berbagai pihak untuk dapat mengikuti semua bentuk kegiatan. Menghadapi tantangan tersebut, guru-guru dituntut untuk lebih menguasai teknologi informasi dan penerapan langsung Iptek di sekolah. Salah satu konsep yang dapat dikembangkan untuk sekolah adalah konsep PjBL dengan berbasis sistem informasi dan komputer. Salah satu hal yang dibutuhkan guru adalah pembelajaran dalam membuat animasi video sedangkan dalam menambahkan wawasan baru siswa/i perlu meningkatkan skill dalam melakukan praktikum di sekolah seperti pengetahuan mengenai robotik. Setelah dilakukan sosialisasi para guru-guru maupun siswa/i SMA IT Baitul Jannah didapatkan hasil evaluasi dari penyuluhan terkait pengenalan robotika sederhana sebanyak 90,44\% siswa yang belum mengetahui robotik sederhana menjadi $100 \%$. Untuk evaluasi penyuluhan terkait pembelajaran menggunakan aplikasi animasi video didapatkan sebanyak 97,62\% menyatakan belum mengetahui dengan jelas aplikasi-aplikasi yang dapat digunakan dalam membuat animasi video menjadi $100 \%$. Hal ini terjadi peningkatan siswa/i maupun para guru yang ingin meningkatkan pemahaman aplikasi sederhana dan dapat dengan mudah mengembangkan media pembelajaran secara animasi dan pengembangan praktik robotik sederhana.
\end{abstract}

ABSTRACK

Improving the quality of education makes technological developments increase as well and forces various parties to be able to participate in all forms of activity. Facing these challenges, teachers are required to better master information technology and the direct application of science and technology in schools. One of the concepts that can be developed for schools is the PjBL concept based on information systems and computers. One of the things that teachers need is learning in making video animations, while in adding new insights students need to improve skills in conducting practicals in schools such as knowledge about robotics. After socializing the teachers and students of SMA IT Baitul Jannah, the evaluation results from counseling related to the introduction of simple robotics were $90.44 \%$ of students who did not know simple robotics to $100 \%$. For the evaluation of counseling related to learning using video animation applications, it was found that $97.62 \%$ stated that they did not know clearly the applications that could be used in making video animations to $100 \%$. This is an increase in students and teachers who want to improve understanding of simple applications and can easily develop animated learning media and develop simple robotic practices. 


\section{JURNAL CEMERLANG: Pengabdian pada Masyarakat \\ P-ISSN 2654-4741 / E-ISSN 2655-7894 \\ Vol. 4, No. 1, Desember 2021, 98 - 108 \\ DOI: https://doi.org/10.31540/jpm.v4i1.1424 \\ PENERBIT: LP4MK STKIP PGRI LUBUKLINGGAU}

Animasi Video, Pandemic covid 19, Project Base Learning,

Robotik, Sekolah Menengah Atas

Video Animation, Pandemic covid 19, Project Base

Learning, Robotics, High School
Received 12 Juni 2021

Revised 05 Oktober 2021

Accepted 17 Desember 2021

CORRESPONDENCE Arlina Phelia@ arlina.phelia@teknokrat.ac.id

\section{PENDAHULUAN}

Pembelajaran adalah salah satu komponen terpenting dari pendidikan dimana peningkatan kualitas pendidikan menjadi faktor utama dalam peningkatan kualitas sumber daya manusia (Gagné, Briggs, \& Wager, 1992; Fitri, Rossi, Suwarni, \& Rosmalasari, 2021). Peningkatan kualitas pendidikan menjadikan perkembangan teknologi semakin meningkat pula dan memaksa berbagai pihak untuk dapat mengikuti semua bentuk kegiatan maupun sistem pendidikan yang harus dijaga dengan baik. Menghadapi tantangan tersebut, guru-guru dituntut untuk lebih menguasai teknologi informasi dan penerapan langsung Iptek di sekolah.

Sebuah media pembelajaran yang menarik bagi siswa/i akan memberikan dampak baik bagi siswa dan menjadi pelajaran favorit. Guru harus mampu memanfaatkan teknologi maupun Iptek dalam melaksanakan proses pembelajaran. Berkaitan dengan hal tersebut indikator dalam mengembangkan model pembelajaran yang terbaru untuk meningkatkan kreativitas siswa adalah dengan pembelajaran Project Base Learning (Prilestari, 2019).

Konsep yang dapat dikembangkan untuk sekolah adalah konsep PjBL dengan berbasis sistem informasi dan komputer. Kegiatan PjBL menekankan pada proses dan produk, dimana para siswa dapat mengatur aktivitasnya dengan menyelesaikan permasalahan melalui proses investigasi (Liegel et al, 2004). Selain siswa/i yang mengembangkan kegiatannya dalam konsep PjBL ini, para guru juga harus mampu meningkatkan media pembelajarannya dengan berbagai teknologi yang merupakan tuntutan revolusi industri 4.0. Di era teknologi seperti sekarang ini, banyak software maupun aplikasi portable yang dapat digunakan 


\section{JURNAL CEMERLANG: Pengabdian pada Masyarakat \\ P-ISSN 2654-4741 / E-ISSN 2655-7894 \\ Vol. 4, No. 1, Desember 2021, 98 - 108 \\ DOI: https://doi.org/10.31540/jpm.v4i1.1424 \\ PENERBIT: LP4MK STKIP PGRI LUBUKLINGGAU}

dalam pembelajaran (Syamsuddin dkk, 2020). Salah satu pengembangan media pembelajaran yang dapat dilakukan guna meningkaatkan konten pembelajaran dari mata pelajaran yang memerlukan visualisasi dapat direalisasikan dengan teknologi AR (Augmented Reality) (Andrian \& Ardiansyah, 2020).

Sasaran dalam pengembangan konsep $\mathrm{PjBl}$ dan media pembelajaran adalah siswa/i maupun guru-guru di SMA IT Baitul Jannah, karena teknologi dengan berbasis sistem informasi dan komputer ini dapat dikembangkan di sekolah menengah atas seperti media animasi, grafis maupun robotik. Memperhatikan kondisi sekolah yang saat ini masih dimasa pandemi, siswa/i SMA diharuskan untuk melakukan aktifitasnya dirumah mulai dari kebutuhan sehari-hari hingga proses pendidikan (Sukmono dkk, 2021). Guru dituntut untuk dapat menguasai berbagai teknologi guna mengembangkan konsep PjBL kepada siswa/i. Media pembelajaran dengan konsep yang menarik akan menjadi mata pelajaran di sekolah yang menarik pula. Kondisi ini harus didukung oleh kualitas guru dan model media pembelajaran yang dapat meningkatkan minat siswa untuk belajar (Endra, Cucus, \& Ciomas, 2020). Guru-guru SMA dalam mengembangkan media pembelajarannya dituntut untuk lebih kreatif sehingga hal ini membutuhkan dukungan teknologi yang sesuai dan mempermudah dalam pembelajaran. Selain mengembangkan di bidang media pembelajaran, guru juga harus mampu memberikan inovasi dari konsep PjBL kepada siswa seperti penggunaan konsep robotik sederhana yang menggunakan alat dan bahan pendukung yang mudah dan sederhana. Hal ini guna diberikan agar siswa/i juga mampu meningkatkan inovasinya dan mengembangkan ide-idenya dibidang sistem informasi dan komputer.

Oleh karena itu, tujuan dari pengabdian kepada masyarakat ini di lingkungan sekolah SMA IT Baitul Jannah adalah meningkatkan pengetahuan dan keterampilan para guru-guru maupun siswa/i melalui pengembangan project base learning dalam bidang animasi video dengan aplikasi. Memberikan pelatihan pengetahuan tentang dasar pembuatan robotik sebagai informasi pembelajaran 


\section{JURNAL CEMERLANG: Pengabdian pada Masyarakat \\ P-ISSN 2654-4741 / E-ISSN 2655-7894 \\ Vol. 4, No. 1, Desember 2021, 98 - 108 \\ DOI: https://doi.org/10.31540/jpm.v4i1.1424 \\ PENERBIT: LP4MK STKIP PGRI LUBUKLINGGAU}

dalam project base learning di sekolah. Memotivasi siswa/i dalam meningkatkan skill praktikum dalam pembelajaran di sekolah. Pengabdian kali ini juga akan memberikan edukasi maupun penerapan dalam konsep $\mathrm{PjBL}$ mengenai pengetahuan terkait animasi video maupun pengenalan robotik sederhana di Sekolah SMA IT Baitul Jannah Bandar Lampung dan bagaimana meningkatkan sistem informasi dalam Project Base Learning di masa pandemi covid-19.

Berdasarkan hasil identifikasi permasalahan, survey lapangan awal dan wawancara singkat yang telah dilakukan dengan Kepala Sekolah dan guru-guru SMA IT Baitul Jannah Bandar Lampung, bahwa pembelajaran dalam PjBL secara praktik masih perlu ditingkatkan. Salah satu hal yang dibutuhkan guru adalah pembelajaran dalam membuat animasi video guna meningkatkan pemahaman siswa/i dimasa pandemi. Selain itu, siswa/i bisa menggunakan animasi video sebagai pembelajaran secara sistem informasi dengan beberapa aplikasi sedangkan dalam menambahkan wawasan baru siswa/i perlu meningkatkan skill dalam melakukan praktikum di sekolah seperti pengetahuan mengenai robotik. Hal tersebut melatarbelakangi usulan untuk kegiatan pengabdian kepada masyarakat di sekolah SMA IT Baitul Jannah dalam penerapan Project Base Learning sehingga pemanfaatan teknologi dan aplikasi dapat menjadi salah satu kegiatan belajar PjBL kepada siswa, dimana dalam penerapannya PjBL juga memberikan dampak positif guna meningkatkan keingintahuan siswa dan memotivasi minat siswa dengan berbasis sistem informasi di sekolah pada masa pandemi covid-19.

\section{METODE}

Kegiatan ini dilakukan selama enam bulan dari Januari hingga Juni Tahun 2021 guna menindaklanjuti permasalahan yang dihadapi oleh mitra. Berikut ini merupakan tahapan-tahapan pelaksanaan pengabdian kepada masyarakat sekolah binaan yang merujuk pada bagan alir dibawah ini Gambar 1. 


\section{Tahapan Persiapan}

- Menganalisis permasalahan yang dihadapi mitra.

- Melakukan koordinasi kepada mitra.

- Merumuskan kebutuhan mitra.

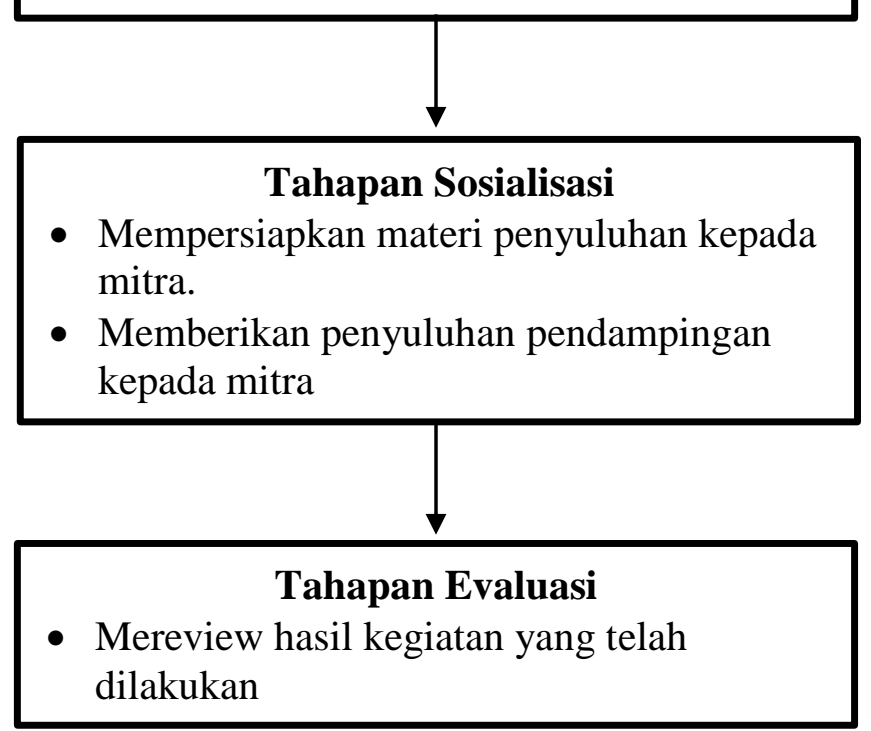

\section{Gambar 1.}

Tahapan Pelaksanaan Kegiatan Pengabdian Kepada Masyarakat SMA IT Baitul Jannah.

Pada tahapan persiapan, dilakukan pendekatan institusional yaitu dengan cara berkomunikasi secara langsung perihal permasalahan yang sedang dihadapi oleh mitra. Selanjutnya adalah menganalisis kebutuhan yang diperlukan mitra berdasarkan permasalahan yang ada. Pada kesempatan ini telah diambil kesimpulan bahwa mitra memerlukan keterampilan dan pengetahuan dalam membuat media pembelajaran serta meningkatkan pengetahuan mitra terhadap konsep PjBL untuk siswa/i maupun guru-guru.

Untuk tahapan sosialisasi, kami mempersiapkan dan menyusun modul maupun bahan paparan yang dapat dimengerti oleh mitra. Materi yang diberikan terkait Project Base Learning berbasis sistem informasi yakni animasi video dan pemahaman sederhana robotik dengan membawa alat robotik sederhana. Kegiatan penyuluhan ini dilaksanakan sekali secara tatap muka dengan tetap mematuhi protokol kesehatan di lingkungan sekolah. Pada saat pelaksanaan penyuluhan, 


\section{JURNAL CEMERLANG: Pengabdian pada Masyarakat \\ P-ISSN 2654-4741 / E-ISSN 2655-7894 \\ Vol. 4, No. 1, Desember 2021, 98 - 108 \\ DOI: https://doi.org/10.31540/jpm.v4i1.1424 \\ PENERBIT: LP4MK STKIP PGRI LUBUKLINGGAU}

kami menggunakan beberapa metode yaitu metode ceramah dan diskusi. Materi sosialisasi yang telah dipersiapkan sebelumnya disampaikan dalam bentuk ceramah dan berdiskusi dengan pemateri guna meningkatkan pemahaman mereka mengenai isi materi sepenuhnya.

Pada tahapan evaluasi dari hasil kegiatan dilakukan untuk dapat mereview rencana yang telah dilakukan sebagai dasar pertimbangan dalam pengembangan skill dan pemahaman siswa/i dalam bidang animasi video dan pemahaman dasar robotik. Kegiatan lain dalam tahap evaluasi ini adalah menyebarkan angket kuesioner secara offline dikelas terkait pemahaman guru-guru dan siswa terkait manfaat dan pemahaman maupun menilai kesesuaian kegiatan yang berlangsung terhadap rancangan awal kegiatan.

\section{HASIL dan PEMBAHASAN}

Kegiatan penyuluhan animasi video dan pengenalan robotik sederhana dalam peningkatan project base learning bagi para guru dan siswa/i SMA IT Baitul Jannah telah dilakukan secara tatap muka di sekolah dengan mengikuti protokol kesehatan yang telah ditetapkan. Kegiatan yang dilaksanakan pada tanggal 31 Maret - 12 April 2021 dihadiri oleh siswa/i, guru-guru, dan Kepala Sekolah SMA IT Baitul Jannah. Setelah mendapatkan kesepakatan waktu pelaksanaan pelatihan selanjutnya memberikan penyampaian materi tentang pentingnya dalam pengelolaan limbah cair skala domestik di sekolah oleh tim pelaksana.

Tim pelaksana yang telah mempersiapkan bahan presentasi penyuluhan tentang proses pembuatan animasi video dan pengantar robotika. Tim pelaksana langsung mendemontrasikan robot sederhana yakni sebuah pesawat baling yang menggunakan sistem sederhana. Peserta (siswa) dapat mengikuti langsung setiap tahapan penjelasan yang diberikan oleh tim pelaksana yakni Mahasiswa Jihad Caesar dengan mempresentasikan animasi video dan Bapak Try Susanto,S.Kom., M.Cs beserta tim mahasiswa sebagai pemateri pengantar robotika. Berikut ada 


\section{JURNAL CEMERLANG: Pengabdian pada Masyarakat \\ P-ISSN 2654-4741 / E-ISSN 2655-7894 \\ Vol. 4, No. 1, Desember 2021, 98 - 108 \\ DOI: https://doi.org/10.31540/jpm.v4i1.1424 \\ PENERBIT: LP4MK STKIP PGRI LUBUKLINGGAU}

dokumentasi dalam penyuluhan pengembangan praktikum animasi video pembelajaran pada Gambar 2.
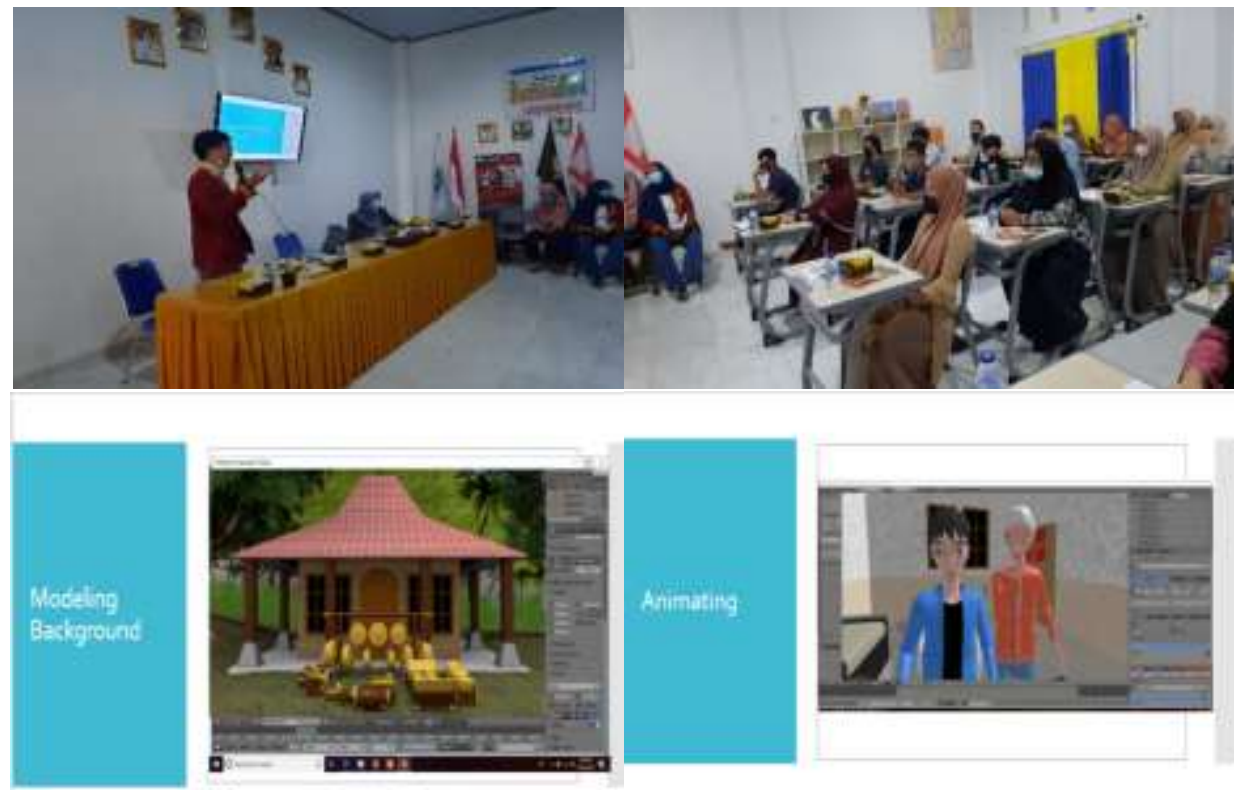

Gambar 2.

Pelaksanaan Penyuluhan Informasi Terkait Animasi Video Pembelajaran

Pada gambar 2 tim pelaksana memberikan sosialisasi kembali dalam peningkatan pembelajaran secara project base learning terkait proses pembuatan video animasi. Pemateri memberikan beberapa langkah - langkah dalam modeling karakter, modeling background, modeling property, animating, proses animating, composting, pembuatan anatomi manusia di blender, serta media pembelajaran AR. Para siswa/i sangat antusias dalam mengikuti kegiatan sosialisasi serta guru - guru sekolah yang senang dengan penambahan wawasan tersebut.

Selain memberikan praktik pelatihan dan sosialisasi, tim pelaksana memberikan informasi dan pengetahuan lain terkait robotik. Sosialisasi ini merupakan praktik pengetahuan yang diberikan kepada siswa/i, guna meningkatkan pengetahuannya di bidang sains. Secara umum robot merupakan sebuah mesin yang mampu mengestrak informasi dari lingkungannya dan menggunakan pengetahuan tentang lingkungannya untuk beraksi secara selamat 


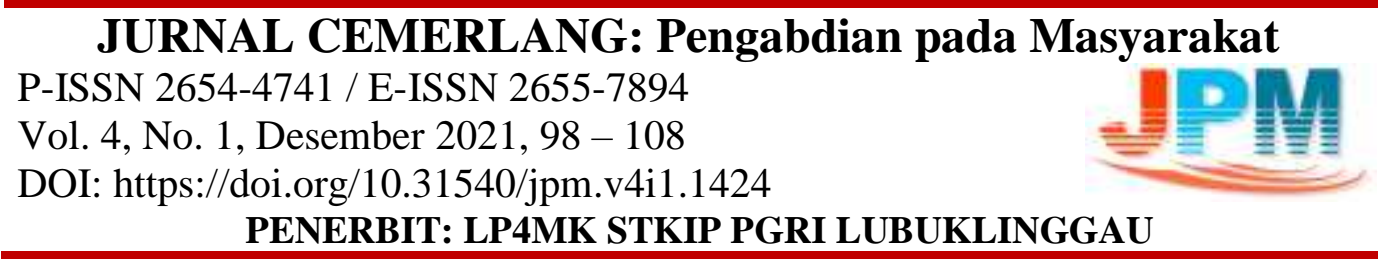

dengan cara yang sesuai yang diinginkan oleh pemrogramannya. Universitas Teknokrat Indonesia bersama tim robotik memberikan sosialisasi umum terkait pemahaman tentang robotik, dimana pemateri memberikan pengertian tentang robotik, bagaimana cara dan macam-macam robot serta mempresentasikan robot sederhana seperti pada Gambar 3.

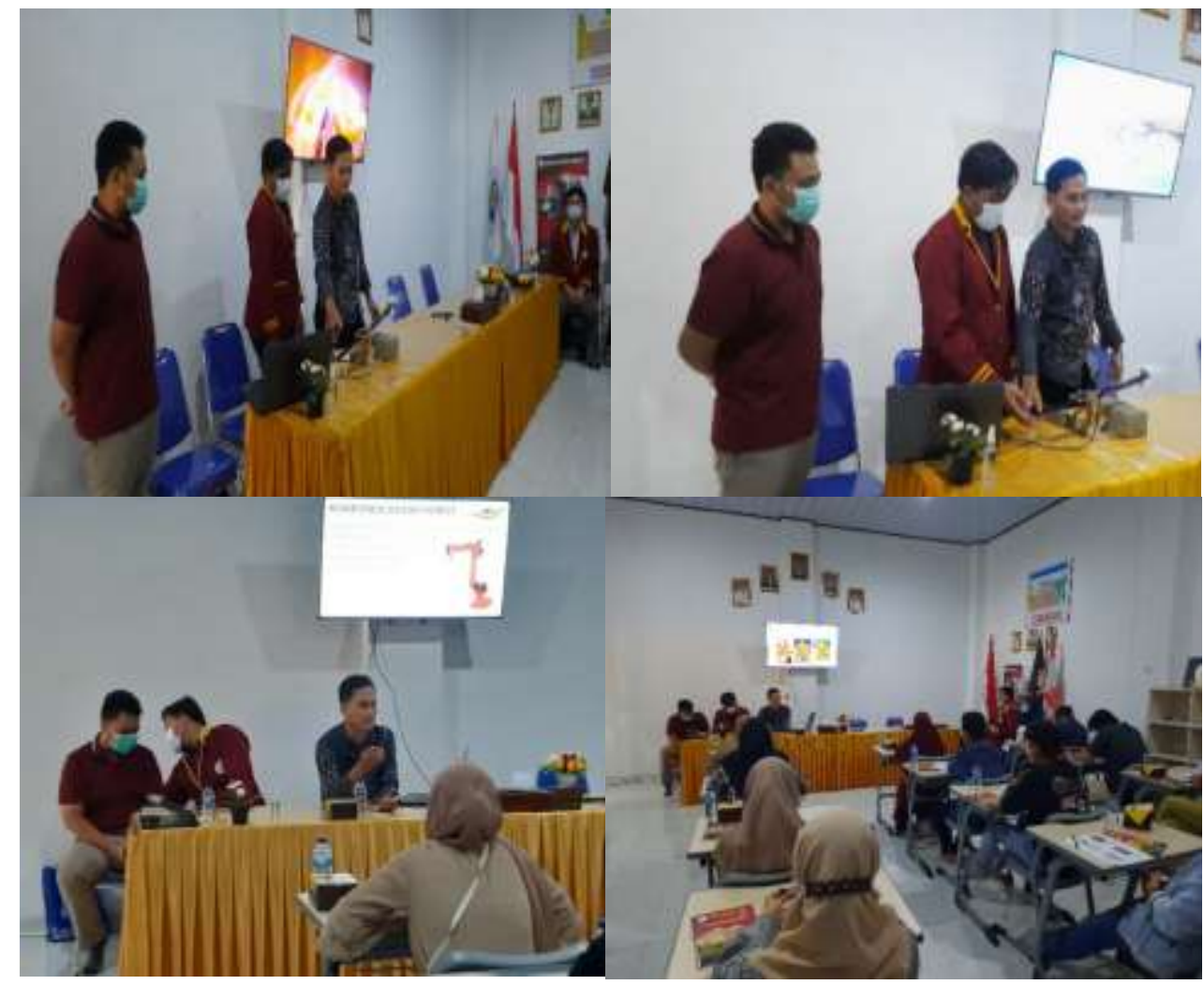

Gambar 3

Kegiatan Sosialisasi dalam pengenalan robotik sederhana

Peningkatan pemberdayaan mitra dilakukan menggunakan kuisioner yang disebarkan kepada civitas akademika SMA IT Baitul Jannah yang terdiri dari siswa/I sebanyak 21 orang. Kuisioner ini diberikan untuk mengetahui apakah terdapat peningkatan pengetahuan dan minat mitra yang diukur sebelum dan sesudah mengikuti penyuluhan pembelajaran animasi video dan pemahaman robotik. Hasil evaluasi kegiatan PKM untuk kegiatan animasi video pembelajaran ini dapat dilihat pada Tabel 1. 


\section{JURNAL CEMERLANG: Pengabdian pada Masyarakat}

P-ISSN 2654-4741 / E-ISSN 2655-7894

Vol. 4, No. 1, Desember 2021, 98 - 108

DOI: https://doi.org/10.31540/jpm.v4i1.1424

PENERBIT: LP4MK STKIP PGRI LUBUKLINGGAU

Tabel 1

Hasil Evaluasi Kegiatan PKM Animasi Video Pembelajaran

\begin{tabular}{|c|c|c|c|c|c|}
\hline \multirow[t]{2}{*}{ No } & \multirow[t]{2}{*}{ Pertanyaan } & \multicolumn{2}{|c|}{ Sebelum } & \multicolumn{2}{|c|}{ Sesudah } \\
\hline & & $\mathrm{Ya}$ & Tidak & $\mathrm{Ya}$ & Tidak \\
\hline 1. & $\begin{array}{l}\text { Pengetahuan anda mengenai animasi } \\
\text { media? }\end{array}$ & 2 & 19 & 21 & 0 \\
\hline 2. & $\begin{array}{l}\text { Apakah anda berminat dalam memahami } \\
\text { pembuatan animasi media? }\end{array}$ & 0 & 21 & 21 & 0 \\
\hline 3. & $\begin{array}{l}\text { Apakah anda memahami apabila } \\
\text { pembelajaran sekolah menggunakan } \\
\text { media animasi? }\end{array}$ & 0 & 21 & 21 & 0 \\
\hline 4. & $\begin{array}{l}\text { Apakah anda ingin membuat tugas dengan } \\
\text { aplikasi dari animasi video yang dijelaskan } \\
\text { guna meningkatkan skill dalam hal } \\
\text { presentasi secara visual sistem informasi? }\end{array}$ & 0 & 21 & 21 & 0 \\
\hline & Nilai Total & 2 & 82 & 84 & $\mathbf{0}$ \\
\hline & Persentase & & $1 \%$ & & $\%$ \\
\hline
\end{tabular}

Dari tabel 1 tersebut terlihat bahwa sebanyak 95,21\% menyatakan bahwa belum mengetahui dengan jelas pembelajaran menggunakan aplikasi animasi video. Selain itu hanya ada dua siswa yang pernah pengetahui mengenai animasi media. Untuk evaluasi dari pemahaman tentang robotika sederhana dijelaskan pada Tabel 2 sebagai berikut.

Tabel 2

Hasil Evaluasi Kegiatan PKM Pengenalan Robotika Sederhana

\begin{tabular}{lllccc}
\hline No & \multicolumn{1}{c}{ Pertanyaan } & \multicolumn{2}{c}{ Sebelum } & \multicolumn{2}{c}{ Sesudah } \\
\cline { 2 - 6 } & Ya & Tidak & Ya & Tidak \\
\hline 1. & $\begin{array}{l}\text { Pengetahuan anda mengenai konsep } \\
\text { robotik sederhana? }\end{array}$ & 2 & 19 & 21 & 0 \\
\hline 2. & $\begin{array}{l}\text { Apakah anda berminat dalam memahami } \\
\text { pembuatan robotik sederhana? }\end{array}$ & 0 & 21 & 21 & 0 \\
\hline 3. & $\begin{array}{l}\text { Apakah anda berminat membuat prakarya } \\
\text { robotik sederhana dan mengikutinya ke } \\
\text { dalam perlombaan? }\end{array}$ & 0 & 21 & 21 & 0 \\
\hline 4. & $\begin{array}{l}\text { Apakah Praktek Seperti Pengetahuan } \\
\text { Animasi dan Robotik bermanfaat bagi } \\
\text { anda? }\end{array}$ & 2 & 19 & 21 & 0 \\
\hline & Nilai Total & $\mathbf{4}$ & $\mathbf{8 0}$ & $\mathbf{8 4}$ & $\mathbf{0}$ \\
\hline & Persentase & & & & \\
\hline
\end{tabular}




\section{JURNAL CEMERLANG: Pengabdian pada Masyarakat \\ P-ISSN 2654-4741 / E-ISSN 2655-7894 \\ Vol. 4, No. 1, Desember 2021, 98 - 108 \\ DOI: https://doi.org/10.31540/jpm.v4i1.1424 \\ PENERBIT: LP4MK STKIP PGRI LUBUKLINGGAU}

Dari tabel 2 tersebut terlihat bahwa sebanyak 90,44\% menyatakan bahwa belum mengetahui dengan jelas praktik pemahaman tentang robotika sederhana. Selain itu hanya ada dua siswa yang pernah pengetahui mengenai konsep dari robotika. Hal ini terjadi peningkatan signifikan yang mana hasil setelah diberikan pengetahuan terkait konsep robotika para siswa/i ingin menggunakan konsep ini dalam sebuah perlombaan nantinya guna meningkatkan potensi para murid dalam mengembangkan inovasi dibidang sistem informasi.

\section{SIMPULAN}

Berdasarkan kegiatan pengabdian yang telah dilaksanakan maka dapat diambil beberapa kesimpulan sebagai berikut :

1. Peserta dapat memahami dalam penyuluhan terkait pembelajaran aplikasi animasi video dan pengantar sederhana terkait robotika di lingkungan sekolah.

2. Hasil evaluasi dari penyuluhan terkait pengenalan robotika sederhana didapatkan sebanyak $9,56 \%$ siswa/i pernah mengetahui tentang robotik sederhana sedangkan $90,44 \%$ siswa belum mengetahui robotik sederhana. Hal ini terjadi peningkatan siswa/i yang ingin mengetahui tata cara praktek dan berminat untuk membuat prakarya praktikum robotik sederhana di sekolah.

3. Untuk evaluasi penyuluhan terkait pembelajaran menggunakan aplikasi animasi video didapatkan sebanyak 2,38\% yang mengetahui tentang beberapa aplikasi animasi video, sedangkan sebanyak 97,62\% menyatakan belum mengetahui dengan jelas aplikasi-aplikasi yang dapat digunakan dalam membuat animasi video. Dari kegiatan ini dapat terlihat peningkatan yang signifikan dimana siswa/i maupun guru dapat memahami aplikasi sederhana yang dapat digunakan dan guru dapat dengan mudah mengembangkan media pembelajaran secara animasi yang mana hal ini termasuk ke dalam bidang sistem informasi. 


\section{JURNAL CEMERLANG: Pengabdian pada Masyarakat \\ P-ISSN 2654-4741 / E-ISSN 2655-7894 \\ Vol. 4, No. 1, Desember 2021, 98 - 108 \\ DOI: https://doi.org/10.31540/jpm.v4i1.1424 \\ PENERBIT: LP4MK STKIP PGRI LUBUKLINGGAU}

Saran yang dapat diberikan adalah mitra sebaiknya memberikan wadah untuk para guru dalam mengimplementasikan pelatihan lanjutan dari beberapa aplikasi terkait animasi video agar para guru dapat dengan jelas memberikan mata pelajaran kepada siswa/i dengan detail berbasis visual gambar.

\section{DAFTAR PUSTAKA}

Andrian, R. \& Ardiiansyah. (2020). Pelatihan Pengembangan Media Pembelajaran Berbasis Augmented Reality (AR) Bagi Guru-Guru SMA Provinsi Lampung. Jurnal Pengabdian Kepada Masyarakat (JPKM) TABIKPUN, 1(1), 55-62.

Endra, R. Y., Cucus, A., \& Ciomas, M. (2020). Penerapan Teknologi Augmented Reality bagi Siswa untuk meningkatkan Minat Belajar Bahasa Mandarin di Sekolah. Jurnal Pengabdian Kepada Masyarakat (JPKM) TABIKPUN, 1(1), 19-30.

Fitri, A., Rossi, F., Suwarni, E., \& Rosmalasari, T. D. (2021). Pelatihan Pembuatan Video Pembelajaran Bagi Guru MA Matha'ul Anwar Lampung Pada Masa Pandemi COVID-19. Jurnal Pengabdian Kepada Masyarakat (JPKM) TABIKPUN, 2(3), 189-196.

Gagné, R. M., Briggs, L. J., \& Wager, W. W. (1992). Principles of Instructional Design (4th ed.). Fort Worth, USA: Harcourt Brace College Publishers.

Liegel, K. M. (2004). Project-Based Learning and the Future of Project Management. Originally Published as a part of 2004 PMI Global Congres Proceedings Anaheim California.

Prilestari, B. D. (2020). Pengembangan Model Project Based Learning (Pjbl) Dalam Meningkatkan Kreativitas Mata Pelajaran Prakarya Sekolah Menengah Pertama (Doctoral dissertation, Universitas Negeri Semarang).

Sukmono, N. D., Pitriani, P., \& Agustinawati, D. (2021). Pelatihan Media Pembelajaran Animasi Huruf Dan Angka Menggunakan Microsoft Power Point dan Kinemaster Sebagai Solusi Pjj Pada Guru TK Di Kabupaten Ngawi. JURNAL CEMERLANG: Pengabdian pada Masyarakat, 3(2), 185195.

Syamsuddin, S., Ahmad, H., Hasliana, L., Latif, A., \& Tasni, N. (2020). PKMPeningkatan Keterampilan Guru Matematika SMK Kabupaten Majene dalam Penggunaan Geoenzo sebagai Media Pembelajaran Matematika. Jurnal Cemerlang: Pengabdian Pada Masyarakat, 3(1), 60-73. 